\title{
Endoglin concentration in peritoneal fluid of patients with endometriosis
}

\author{
Nusratuddin Abdullah \\ Department of Obstetric \& Gynecology, Hasanuddin University, Makassar, Indonesia
}

\begin{abstract}
Abstrak
Latar belakang: Endoglin adalah faktor angiogenesis spesifik yang diduga terkait dengan patogenesis endometriosis. Tujuan penelitian ini adalah mengevaluasi hubungan kadar endoglin pada cairan peritoneum pasien dengan endometriosis.

Metode: Penelitian ini merupakan penelitian observasional potong lintang yang dilaksanakan pada bulan Maret 2011 sampai Juli 2012 di RS Dr. Wahidin Sudirohusodo dan rumah sakit swasta di Makassar. Semua pasien yang akan menjalani laparoskopi untuk masalah infertilitas dan masalah lainnya serta memenuhi kriteria inklusi diminta untuk mengisi kuesioner dan diambil cairan peritoneum sebanyak 5 cc untuk mengukur kadar endoglin dengan metode ELISA. Stadium endometriosis ditegakkan dengan memakai kriteria ASRM dan dipisahkan menjadi endometriosis ringan dan berat. Data dianalisis dengan Excel dan analisis korelasi Spearman.
\end{abstract}

Hasil: Pada kelompok endometriosis didapatkan konsentrasi endoglin antara 14,43-15,65 ng/mL (median 15,04 ng/mL) sedangkan pada kelompok kontrol antara 7,42-10,26 $\mathrm{ng} / \mathrm{mL}$ (median 8,84 $\mathrm{ng} / \mathrm{mL}$ ). Kadar endoglin peritoneum sama atau lebih tinggi dari $11 \mathrm{ng} / \mathrm{mL}$ mungkin dipakai sebagai titik potong prediktor kasus endometriosis.

Kesimpulan: Kadar endoglin peritoneum meningkat secara proporsional sesuai dengan meningkatnya stadium endometriosis, sehingga kadar endoglin dapat dipakai sebagai prediktor endometriosis. (Med J Indones. 2013;22:88-91)

\begin{abstract}
Background: Endoglin is a specific angiogenic factor suspected to involve in the pathogenesis of endometriosis. The aim of this study was to evaluate the significance of endoglin concentration in the peritoneal fluid of patients with endometriosis.

Methods: This pilot study was performed between March 2011 and July 2012 at Dr. Wahidin Sudirohusodo Hospital and another private hospital in Makassar, Indonesia. This was an observational, cross-sectional study. All patients undergoing laparoscopy for infertility and other cases with suitable inclusion criteria were asked to answer a questionnaire and had a 5 cc peritoneal fluid sample taken for measurement of peritoneal endoglin concentration using ELISA. Endometriosis stage was classified using ASRM criteria and divided into two groups, mild and severe. All data were analyed using Excel and Spearman correlation analysis.
\end{abstract}

Results: In the endometriosis group peritoneal endoglin concentration ranged between $14.43-15.65 \mathrm{ng} / \mathrm{mL}$ (median 15.04 $\mathrm{ng} / \mathrm{mL}$ ) which is higher than control group 7.42-10.26 ng/mL (median $8.84 \mathrm{ng} / \mathrm{mL}$ ). A peritoneal endoglin concentration equal to or higher than $11 \mathrm{ng} / \mathrm{mL}$ could be used to predict endometriosis.

Conclusion: Endoglin concentrations increased proportionally with the severity of endometriosis, and many be used as predictive factor of endometriosis cases. (Med J Indones. 2013;22:88-91)

Keywords: Endoglin, endometriosis, peritoneum

Endometriosis is a complex disease characterized by the presence of extra uterine endometrial glands and stroma. It is multi-factorial in origin and is associated with pain and infertility. Endometriosis affects the lives of millions of women all over the world. Early diagnosis of the disease is still a challenge and laparoscopy remains the diagnostic gold standard. ${ }^{1}$

A unifying theory regarding the origin of endometriosis remains elusive. The most widely accepted theory is the implantation theory of Sampson (1927). He proposed that endometrial tissue is shed through the Fallopian tubes into the peritoneal cavity during menstruation, where it attaches and proliferates at ectopic sites of angiogenesis, ${ }^{2}$ i.e. the development of new blood vessels from pre-existing ones, which represents a crucial step during this process, as with tumors metastases, since endometriotic implants require neovascularization to guarantee oxygen and essential nutrient supply necessary for growth. ${ }^{3-5}$

Many literature reports highlight that both the serum and peritoneal fluid of women with endometriosis have elevated levels of activated macrophages, cytokines, and growth factors. ${ }^{1}$ Many investigators still focus their research on peritoneal fluid and endometriotic lesions to advance their knowledge of the pathogenesis of endometriosis. Previous studies on endometriosis identified significant endoglin expression in endometriotic lesions. ${ }^{6-8}$ These studies were also supported by Pelch et al on gene expression analysis using a mouse model of surgically induced endometriosis which showed that the endoglin gene was expressed 2.2 times greater in early stage establishment of endometriotic lesions (3 days). ${ }^{9}$ 
Endoglin is an endothelial cell-specific angiogenic factor suspected to involve in the pathogenesis of endometriosis by establishing a new blood supply. ${ }^{10}$ The expression of endoglin is elevated on the endothelial cells of healing wounds, developing embryos, inflammatory tissues, and solid tumors. Endoglin is a marker of activated endothelium, and its vascular expression is limited to proliferating cells. Recent studies identified endoglin expression in several solid tumor types, with the level of expression correlating with various clinico-pathologic factors including decreased survival and presence of metastases. ${ }^{11,12}$

Using the analogy of tumor metastasis, some researchers postulated the angiogenic potential of the endometrium or the intra-peritoneal environment potentiated endometriotic lesion establishment. Indeed, endometriotic implants often are surrounded by a web of blood vessels., ${ }^{4,5,13}$ Based on this analogy, it is assumed that endoglin could be used as a biomarker for intra-peritoneal endometriosis activity. The aim of this study was to evaluate endoglin concentration in peritoneal fluid of patients with endometriosis and show its association with the degree of severity of the disease.

\section{METHODS}

This cross-sectional, pilot study was performed between March 2011 and July 2012 at Dr. Wahidin Sudirohusodo Hospital and another private hospital in Makassar, Indonesia. This study has been approved by Ethical Clearance Committee in Faculty of Medicine Hasanuddin University.

The study populations were patients undergoing laparoscopy for infertility cases, suspected endometriosis, and other cases in which laparoscopy is used as a diagnostic tool. Inclusion criteria were: 1) Agree to participate in the study by signing the inform consent and have a laparoscopy procedure; 2) diagnosis was confirmed by physical examination, ultrasound, and laparoscopy; 3) no limitation in age. Exclusive criteria were: 1) Incomplete data and fail to follow study procedure; 2) the finding of sign of pelvic inflammatory disease or malignancy during laparoscopy procedure; 3 ) failure to collect peritoneal fluid during laparoscopy; 4) under endometriosis therapy or ovarian suppression within the last six months; 5) pregnancy, confirmed by laboratory test and US; 6) menstruation; 7) in period of wound healing; 8 ) other diseases which could increase angiogenesis process such as: hereditary hemorrhagic telangiectasia, severe infection, malignancy.
All laparoscopy patients with suitable inclusion criteria were asked to answer a questionnaire and had a $5 \mathrm{cc}$ peritoneal fluid sample taken for measurement of endoglin concentration. All of peritoneal fluid sample were frozen at $-40^{\circ} \mathrm{C}$ until essay of endolgin. Endoglin measurement was performed using ELISA. Endometriosis was classified using ASRM criteria and divided into two groups: mild endometriosis (stage I and II) and severe endometriosis (stage III and IV).

All data were analyed using Excel and Spearman correlation analysis using Statistical Package for Social Sciences (SPSS) for Windows version 17.

\section{RESULTS}

Table 1 shows the sample characteristics in this study. There were 80 patients in the study of which 58 had endometriosis and 22 were used as the control. The ages of the study participants ranged from 23 to 51 years (mean 34.6 years). The main indication for laparoscopy was primary infertility 48 cases $(60 \%)$ and secondary infertility in 23 cases $(28.8 \%)$. Nine cases were not associated with infertility and indication for the laparoscopy included ovarian cyst, uterine myoma, and adhesions. Almost all of sample were married $n=73(91.3 \%)$ and 49 subjects $(61.3 \%)$ had never been pregnant. Sixty five patients $(81.3 \%)$ complained of dysmenorrhea.

Table 1. Sample characteristic

\begin{tabular}{lc}
\hline Characteristic & $\mathrm{n}(\%)$ \\
\hline Marital status & $73(91.3)$ \\
Married & $7(8.7)$ \\
Unmarried & $7(8.7)$ \\
Parity $\quad$ Unmarried & $49(61.3)$ \\
PoAo & $24(30.0)$ \\
Other & $48(60.0)$ \\
Infertility & $23(28.8)$ \\
Primary infertility & $9(11.2)$ \\
Secondary infertility & \\
No infertility & $65(81.3)$ \\
Dysmenorrhea & $15(18.7)$ \\
Yes & \\
No & $58(72.5)$ \\
No & $22(27.5)$ \\
\hline
\end{tabular}


In the endometriosis group, peritoneal endoglin concentration ranged between 14.43-15.65 ng/mL (median $15.04 \mathrm{ng} / \mathrm{mL}$ ) and in the control group 7.42-10.26 $\mathrm{ng} / \mathrm{mL}$ (median $8.84 \mathrm{ng} / \mathrm{mL}$ ). Patients with endometriosis have a higher peritoneal endoglin concentration compared with the control group. Figure 1 shows in more detail that peritoneal endoglin concentration increased gradually with an increase of the stage of endometriosis. Using peritoneal endoglin concentration of $11 \mathrm{ng} / \mathrm{mL}$ as a cut-off, patients were divided into the case group (endometriosis) and the control group (no endometriosis). Cut-off level of $11 \mathrm{ng} / \mathrm{mL}$ was justified using receiver operating characteristic (ROC) curve analysis. Statistical analysis showed that there was a strong correlation between peritoneal endoglin concentration with endometriosis stage $(r=0.737)$.

\section{DISCUSSION}

In this study, the sample characteristic showed an average age of 34.6 years which is different from other reports. Kim et al found an average of 40 years and Abdullah in Makassar reported an age average of 32 years. ${ }^{14,15}$ The pre-dominant symptom found in this study was dysmenorrhea in 65 cases (81.3\%). Of these, 65.58 (90\%) also complained of infertility. Of the 58 subjects who had dysmenorrhea and infertility, laparoscopy confirmed the diagnosis of endometriosis in 51 subject $(88 \%)$. This study confirmed other investigators results that the symptoms of dysmenorrhea and infertility have high association with endometriosis $(80-90 \%) .{ }^{16-18}$
Evaluation of peritoneal fluid has shown biomarkers such as interleukin- 6 , transforming growth factor- $\beta$ (TGF- $\beta$ ), tumor necrosis factor- $\alpha$ (TNF- $\alpha$ ), macrophage migration inhibitory factor (MIF), matrix metalloproteinase (MMP), vascular endothelial growth factor (VEGF) and others which have link with inflammation and angiogenesis of endometriosis activity. ${ }^{1,19-21}$ Endometriosis angiogenesis activity has been shown by some investigators during laparoscopy with endometriotic implants often surrounded by a web of blood vessels. ${ }^{4,5,13,18}$

This study has led to the possibility that the angiogenic potential of the endometrium or the intra-peritoneal environment can potentiate establishment of lesion. As a result, it is postulated that an angiogenic biomarker should be a reasonable biomarker to predict the severity of endometriosis cases.

Endoglin has been used as angiogenic biomarker for malignancy cases. Endoglin is found on peri-tumoral and intra-tumoral vessels. ${ }^{10,12,22}$ Studies have shown that angiogenic activity in endometriosis acts like a tumor metastasis. ${ }^{4-6,13}$ We believe that endoglin is a potential biomarker to predict endometriosis. Some investigators have already used immune-histochemistry to show endoglin expression in endometriosis tissue. ${ }^{6-8}$ Gene expression analysis using a mouse model of surgically induced endometriosis has also shown that the endoglin gene was expressed 2.2 times greater during early stage development of endometriotic lesions (3 days). ${ }^{9}$

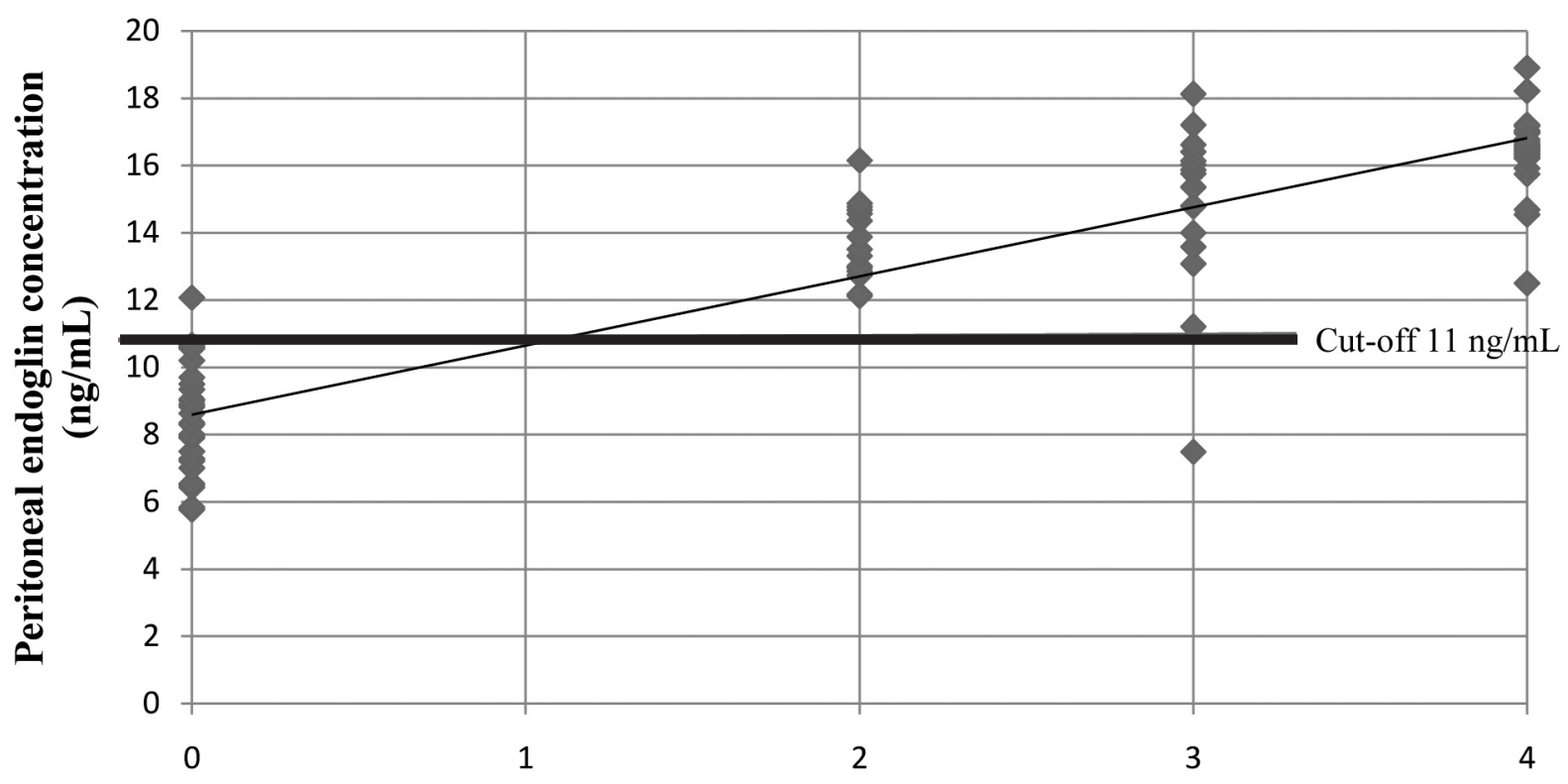

Endometriosis stage

Figure 1. Scatter graph of peritoneal endoglin concentration and the correlation with endometriosis stage 
This research show a higher peritoneal endoglin concentration in endometriosis cases compared with the control group. There was a statistically high correlation between peritoneal endoglin concentration with endometriosis stage. Figure 1 also shows gradual increase of peritoneal endoglin concentration following endometriosis stage. Based on this study, endoglin concentration could be used as biomarker to predict endometriosis cases. A peritoneal endoglin concentration of $11 \mathrm{ng} / \mathrm{mL}$ has been used as the upper limit of normal and higher values shomed the presence of endometriosis.

This study supports the postulate that there is a local angiogenesis process in the peritoneal cavity of endometriosis cases. In this study, the author believes that endoglin concentration in peritoneal fluid could be a useful biomarker. This study also arises an idea to assess possibility that pre-operative serum endoglin concentration can be used as a predictor of suspected endometriosis cases.

In conclusion, this study has shown that peritoneal endoglin concentration is higher in endometriosis group compare with control group. Endoglin concentration increases gradually in parallel with the worsening stages of endometriosis. Using a peritoneal endoglin concentration of $11 \mathrm{ng} / \mathrm{mL}$ as the upper limit of normal higher levels could be used to prediot patients with and without endometriosis.

Further studies are needed to find an absolute correlation between serum endoglin concentration and stage of endometriosis. Measurement of serum endoglin may become a useful predictor pre-operatively in cases of suspected endometriosis.

\section{REFERENCE}

1. Gupta S, Agarwal A, Sekhon L, Krajcir N, Cocuzza M, Falcone T. Serum and peritoneal abnormalities in endometriosis: potential use as diagnostic markers. Minerva Ginecol. 2006;58(6):527-51.

2. Burney RO, Giudice LC. Pathogenesis and pathophysiology of endometriosis. Fertil Steril 2012;98(3):511-9.

3. Groothuis PG, Nap AW, Winterhager E, Grummer R. Vascular development in endometriosis. Angiogenesis 2005;8(2):147-56.

4. Nap AW, Griffioen AW, Dunselman GA, et al. Antiangiogenesis therapy for endometriosis. J Clin Endocrinol Metab. 2004;89(3):1089-95.
5. Taylor RN, Yu J, Torres PB, et al. Mechanistic and therapeutic implications of angiogenesis in endometriosis. Reprod Sci. 2009;16(2):140-6.

6. Hayrabedyan S, Kyurkchiev S, Kehayov I. Endoglin (cd105) and S100A13 as markers of active angiogenesis in endometriosis. Reprod Biol. 2005;5(1):51-67.

7. Kim SH, Choi YM, Chae HD, Kim KR, Kim CH, Kang $\mathrm{BM}$. Increased expression of endoglin in the eutopic endometrium of women with endometriosis. Fertil Steril 2001;76(5):918-22.

8. Fujishita A, Hasuo A, Khan KN, Masuzaki H, Nakashima $\mathrm{H}$, Ishimaru T. Immunohistochemical study of angiogenic factors in endometrium and endometriosis. Gynecol Obstet Invest. 1999;48 Suppl 1:36-44.

9. Pelch KE, Schroder AL, Kimball PA, Sharpe-Timms KL, Davis JW, Nagel SC. Aberrant gene expression profile in a mouse model of endometriosis mirrors that observed in women. Fertil Steril 201015;93(5):1615-27 e18.

10. Banerjee S, Dhara SK, Bacanamwo M. Endoglin is a novel endothelial cell specification gene. Stem Cell Res. 2012;8(1):85-96.

11. Perez-Gomez E, Del Castillo G, Juan Francisco S, LopezNovoa JM, Bernabeu C, Quintanilla M. The role of the TGF-beta coreceptor endoglin in cancer. ScientificWorldJournal 2010;10:2367-84.

12. Dallas NA, Samuel S, Xia L, et al. Endoglin (CD105): a marker of tumor vasculature and potential target for therapy. Clin Cancer Res. 2008;14(7):1931-7.

13. Healy DL, Rogers PA, Hii L, Wingfield M. Angiogenesis: a new theory for endometriosis. Hum Reprod Update. 1998;4(5):736-40.

14. Abdullah N. Analysis of vascular endothelial growth factor (VEGF) gene polymorphisms in endomometriosis. Makassar: Universitas Hasanuddin; 2008. Indonesian.

15. Kim SH, Choi YM, Choung SH, Jun JK, Kim JG, Moon SY. Vascular endothelial growth factor gene $+405 \mathrm{C} / \mathrm{G}$ polymorphism is associated with susceptibility to advanced stage endometriosis. Hum Reprod. 2005;20(10):2904-8.

16. Cramer DW, Missmer SA. The epidemiology of endometriosis. Ann N Y Acad Sci. 2002;955:11-22.

17. McLeod BS, Retzloff MG. Epidemiology of endometriosis: an assessment of risk factors. Clin Obstet Gynecol. 2010;53(2):389-96.

18. Chu KK, Chen FP, Chang SD. Prevalence of endometriosis among women undergoing laparoscopic procedures. Diagnostic and Therapeutic Endoscopy 1995;2(1):35-7.

19. Bedaiwy MA, Falcone T. Laboratory testing for endometriosis. Clin Chim Acta. 2004;340(1-2):41-56.

20. Taylor RN, Lebovic DI, Mueller MD. Angiogenic factors in endometriosis. Ann N Y Acad Sci. 2002;955:89-100.

21. Kadija S, Stefanovic A, Jeremic K, et al. The utility of human epididymal protein 4 , cancer antigen 125 , and risk for malignancy algorithm in ovarian cancer and endometriosis. Int J Gynecol Cancer. 2012;22(2):238-44.

22. Maio M, Altomonte M, Fonsatti E. Is it the primetime for endoglin (CD105) in the clinical setting? Cardiovasc Res. 2006;69(4):781-3. 